\title{
Mantar Yönetim Algısının İş Tatminine Etkisinde Yabancılaşmanın Aracı Rolü
}

\author{
DOI: 10.26466/opus. 845473
}

*

\section{Olgun Irmak Cetin *}

* Dr. Öğr. Üyesi, Trakya Üni., Keşan Yusuf Çapraz Uygulamalı Bilimler Y.O, Keşan/Edirne E-Posta: oirmakcetin@trakya.edu.tr

ORCID: $0000-0002-2534-944 \mathrm{X}$

\section{Öz}

Bu çalışma, mantar yönetim algısı yaşayan işgörenlerin, işe yönelik tatminine yabancilaşmanın aracı etkisini araştırmayı hedeflemektedir. Çalışma, kavramsal çerçeve, metodoloji, bulgular, tartışma ve sonuç kısımlarından oluşmaktadır. Kavramsal çerçevede çalışmanın değişkenleri olan Mantar yönetim, İş tatmini ve Yabancılaşma hakkında literatür taraması gerçekleştirilmiş, değişkenler arası ilişkilere yönelik yapılmış çalışmalar incelenmiştir. Çalışmanın metodolojisinde, anket yöntemi kullanılarak elde edilen veriler değerlendirilmiştir. Araştırmanın evrenini İstanbul ve Bursa illerinde ev tekstili sektöründe çalışan işgörenler ve örneklemini ise İstanbul ve Bursa illerinden seçilmiş ev tekstili sektöründe çalışan işgörenler meydana getirmektedir. Ankete Bursa'dan 58, İstanbul'dan 73 katılımcr iştirak etmiştir. Toplamda 131 katıllmo ile anket gerçekleştirilmiştir. Anketler online olarak ulaştırılmış ve veriler SPSS programı ile incelenmiştir. Çalışmanın bulgular kısmında SPSS programı kullanılarak analiz geçekleştirilmiştir. Veri setinin öncelikle geçerlilik ve güvenilirlikleri kontrol edilmiştir. Analizler neticesinde elde edilen bulgulara göre Mantar yönetim algısı ve İş tatmini ilişkisinde Yabancılaşmanın aracı etkiye sahip olduğu anlaşılmıştır. Çalışmanın sonuç kısmında aracı değişken özelliği gösteren Yabancılaşmanın, Mantar yönetim algısına sahip olan işgörenlerde İş tatminini azalttığı ve tatminsizlik meydana getirdiği açıklanmıştır.

Anahtar Kelimeler: Mantar yönetim, İş tatmini, Yabancılaşma, Hiyerarşik regresyon analizi 


\title{
The Mediating Role of Alienation in the Effect of Mushroom Management Perception on Job Satisfaction
}

\begin{abstract}
This study aims to investigate the mediating effect of alienation on job satisfaction of employees with a mushroom management perception. The study consists of conceptual framework, methodology, findings, discussion and conclusion sections. In the conceptual framework, literature review on Mushroom management, Job satisfaction and Alienation, which are the variables of the study, was conducted, and studies on the relationships between variables were examined.In the methodology of the study, the data obtained using the questionnaire method were evaluated. The universe of the research consists of the employees working in the home textile sector in Istanbul and Bursa provinces and the sample is composed of the employees working in the home textile sector selected from Istanbul and Bursa provinces. 58 participants from Bursa and 73 participants from Istanbul participated in the survey. The survey was conducted with a total of 131 participants. The questionnaires were delivered online and the data were analyzed with the SPSS program. In the findings part of the study, analysis was made using the SPSS program. The validity and reliability of the data set were first checked.According to the findings obtained as a result of the analysis, it has been understood that Alienation has a mediating effect in the relationship between mushroom management perception and job satisfaction. In the conclusion part of the study, it was explained that Alienation, which shows the mediator variable feature, decreases job satisfaction and causes dissatisfaction in employees with mushroom management perception.
\end{abstract}

Keywords: Mushroom management, Job satisfaction, Alienation, Hierarchical regression analysis 


\section{Giriş}

21. yy'da işletmeler, piyasa koşullarında mücadele etmek için, dinamizm yeteneğine değer vermelidirler. Bunu hızlı ve etkili bir şekilde başarmak, işletmelerin ancak işgücü yönetimi ile aynı sayfada olduğunda mümkün olacaktır. Bilgilerin çalışanlara etkili bir şekilde iletilmesi, inovasyon, müşteri hizmetleri, vasıflı işgücünü elde tutma ve nihayetinde değişim için çok önemlidir.

İşletmeler, devamlılıklarını sağlayabilmek için iletişime önem vermelidirler. İletişimde karşılıklılık esası çiğnendiğinde durum sadece "erişim" ile s1nırlı kalmaktadır. Buna dayanarak işletmeleri yüksek ya da düşük erişimli olarak ikiye ayırmak mümkündür. Yüksek erişime sahip işletmeler, azami ölçüde paylaşılan bilginin ulaşılabilirliği ile karakterize edilirler. Daha fazla içgörüye sahip olmak, çalışanların müşteri ihtiyaçlarındaki değişime daha iyi uyum sağlamasına ve sürekli değişen ortama yanıt vermesine olanak tanır. Düşük erişimli işletmeler, bilgiye sınırlı erişim ile karakterize edilirler. İletişim akışı tıkanmış ve engellenmiştir. Tipik olarak, bu gibi organizasyonlardaki işgörenler tıpkı mantarlar gibi karanlıkta kalırlar. Zorlu iş tanımları, sıralama ve hiyerarşik konum nedeniyle gerilirler. Düşük erişimli işletmeler, değişime yanıt vermekte gecikir, dinamizm yeteneği elde edemezler. Yönetim modeli olarak mantar yetiştiriciliğine benzer bir yapıya sahiptirler.

Mantar yönetim, mantarlara özgü bakım özelliklerinin bir metafor olarak değerlendirilmesi sonucu yönetim literatüründe yer edinmiştir. Mantar yetiştiriciliği baz alınarak işgörenlerin karanlıkta bırakılması sonucu bilgi akışından yararlanamamasıdır. İşgörenler, mantarlarda olduğu gibi karanlıkta gübre ile beslenir yani talimatlar ile yönlendirilir. Talimatlara ilişkin açıklama yapılmaz, bilgi verilmez, bir sebep-sonuç ilişkisine yer verilmez. Çağdışı bir uygulama olmasına rağmen Mantar yönetim örneklerine rastlamak mümkündür. Mantar yönetimi benimsemiş işletmelerde işgörenler, işe yönelik olumsuz tutum geliştirebilir ve işten ayrılma niyetine girebilir. Bunun bir sebebi de iş tatmininin azalması olarak gösterilebilir. İş tatmini, işgörenlerin işe yönelik tutumlarını tespit etmektedir. Yöneticiler, işgörenin işe yönelik tatmin duygusunu maksimize etmeyi; işgören ise emeği karşılığında çalıştığ kurumdan kazanımlarını maksimize etmeyi hedefler. Denge kurulduğunda işgörenin işe yönelik tatmin veya tatminsizliği anlaşılabilir hale gelecektir. İş- 
gören iş tatminsizliği yaşamakta ise işe Yabancılaşmaya başlar. Bu sürecin sonunda işgörende İşten ayrılma niyeti gelişir. Yabancılaşma, eskiden beri var olan bir kavram olagelmiştir.

\section{Kavramsal Çerçeve}

Çalışmanın bu kısmında Mantar yönetim, İş tatmini ve Yabancılaşma hakkında kavramsal bilgi verilecek, değişkenler arası ilişkiler ele alınacaktır.

\section{Mantar yönetim}

Artan küresel rekabetle birlikte teknolojinin itici gücü, kurumların yeni yönetim anlayışlarını ve stratejilerini benimseyerek uygulamalarını gerekli kılmıştır (Atagan Çetin, 2017). Mantar yönetimin temelinde, mantarların karanlıkta bırakılarak yetiştirilmesi yönteminin metafor olarak kullanılması yer almaktadır (Kahya ve Ceylan, 2019). İşgörenlerin bilgiye ulaşılmasının önüne geçilerek karanlıkta bırakılması sureti ile yöneticinin, iletişimde tek yönlülüğe mahrum kalması olarak değerlendirilmektedir (Kılıç ve Olgun, 2017). Yani mantar yönetimi, yöneticilerin işgörenleri mantar yetiştiriciliği gibi karanlıkta tuttuğu ve performanslarını artırma düşüncesi ile işgörenlere, talep edilen kaynakların verildiği metaforik bir teori olarak görülmektedir (Külekçi, Özbozkurt ve Bahar, 2020). İşletmede hissedilir düzeyde bilgi asimetrisi ve iletişimsizlik bulunmaktadır (Kahya ve Ceylan, 2019). Bilgi asimetrisi, bilinen bir bilgiyi başkasının bilmemesi durumudur. Bunun tersi de doğru olmakla birlikte bilgi paylaşımında bulunulmayan ve değişime kapalı olan işletmeler, Mantar yönetim tuzağına düşebilmektedir (Çınar ve Toker, 2019).

Mantar yönetimde, yöneticiler, sahip olduğu bilgiyi işgörenler ile paylaşmaktan kaçınmakta ve işgörenlere talimatlar vererek onların çalışmasını sağlamaktadır. Bunun sebebi yöneticilerin, işgören tarafından getirilecek sorgu ve eleştirilerden uzak durmak istemesi olabilir. Ayrıca Mantar yönetimin uygulanması ile yöneticiler, karar verme sürecinde yaşanılan yanlışları kamufle edebilmektedirler (Gunn, 1995). Verilen bu olumsuz nedenlere rağmen işletme yönetiminin, Mantar yönetim algısı yaratmasının olumlu olduğu düşünülen bir sebebi vardır. Karanlıkta yetiştirilen mantarların, daha hızlı büyümesi ve çoğalması gibi, bilgi paylaşımında bulunulmayan ve karanlıkta bırakılarak iletişimsiz kalan işgörenlerin performansının artacağı düşünülmektedir (Birincioğlu ve Tekin, 2018). 
Mantar yönetim anlayışında yöneticiler genellikle Şekil 1'de verilen yanlışlara düşerler (Mar, 2017).

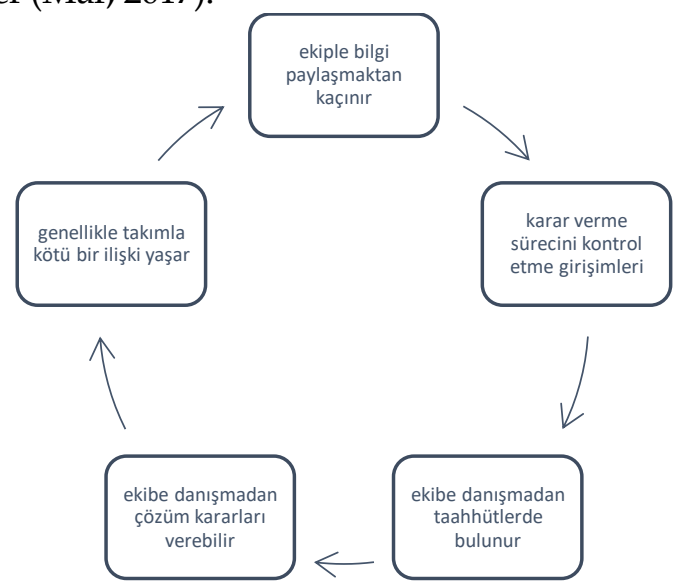

Şekil 1. Mantar yönetimde yöneticilerin yanlışlar

Şekilden görüldüŭgu üzere Mantar yönetim tarzını uygulayan yöneticiler, işgörenleri kontrol edebilmek için kasıtlı olarak bilgi paylaşımında bulunmamaktadır.

Kahya ve Ceylan' dan (2019) aktaran Ergün (2020) işletmelerin, Mantar yönetim algısından kurtulmak için işgörenlerce benimsenmiş katılımcı ve şeffaf yönetim anlayışı geliştirmesi, tüm sürecin denetime ve ölçüme imkan vermesi ve verilerin işgörenlerle paylaşılması gerektiğini öne sürmüştür.

Birincioğlu ve Tekin (2018) Mantar yönetim uygulamasının çeşitli sorunlara yol açacağını öne sürmektedir. 
İşgörenlerin, işletmeden ayrılma niyetinde artışa yol açabilir

İşgörenlerin, işetmeye olan güveninin azalmasına neden olabilir.

Bir arada çalışan üst ve astlar arasında bilgi paylaşımının adil olmaması

sebebiyle üstlerin çok daha güçlü olduğu algısının yaratılmasına sebep olabilir .

Yöneticilerde güç zehirlenmesi yaratabilir.

Astlar, işletmede neler olup bittiğini öğrenmek için çok fazla zaman harcayabilirler.

İşletmede dedikodu ağı gibi informal bilgi akışı meydana gelebilir.

Şekil 2. Mantar yönetimin sonuçlarn

Şekilde verilen tüm olumsuz sonuçlar, işgören performansında düşüklüğe yol açacaktır. Mantar yönetiminin egemen olduğu işletmelerde üstler astlarına belli bir iş vermekte ancak neyi neden yapmaları gerektiğini açılama gereksiniminde bulunmamaktadırlar (Tekin ve Birincioğlu, 2017).

\section{İş tatmini}

İş tatmini, Endüstri ve Örgütsel Psikoloji alanında tutuma yönelik olarak en kapsamlı araştırılan konular arasındadır (Amoah, 2020). İş tatmininin çeşitli iş aktiviteleri ve ödülleri yaşayarak kazanılan tatmin olduğu düşünüldüğünde, işe yönelik bireysel davranış ve iş hakkındaki olumlu düşüncelerin İş tatmininin konusunu oluşturduğu anlaşılacaktır (Essien, 2020). En basit ifade ile İş tatmini, işgörenin işinden ne kadar memnun olduğudur (Paithankar). Farklı kaynaklarda İş tatmini, işgörenin işini veya iş ile ilgili yaşadıklarını gözden geçirmesi neticesinde sahip olduğu olumlu görüş şeklinde tanımlanmaktadır (Alnıaçık, Pamuk ve Alnıaçık, 2020). Diğer bir değişle, işgörenlerin hali hazırda devam eden işlerini kapsayan inançların tümünü ifade etmektedir (Y. Çelik ve Demir, 2020). İş tatmini, işletme literatüründe uzun yıllardır üzerinde araştırmalar yapılan bir konu olması hasebi ile hem insan kaynakları hem de davranış bilimleri için önemli içeriklere sahiptir (Yücekaya ve Dönmez Polat, 2020). Genel bir tanım Aşan ve Erenler (2008) tarafından “İşs tatmini, iş şartlarının (işin kendisi, yönetimin tutumu) ya da işten elde edilen sonuçların ( ücret, iş güvenliği) kişisel bir değerlendirmesidir ve bireyin normlar, değerler, beklentiler sisteminden geçerek işlenen iş ve iş koşullarına 
ilişkin algılamalarına karşı geliştirdiği içsel tepkilerden oluşmaktadır" şeklinde yapılmıştır.

İş tatmininin bilişsel ve duyusal bileşenleri olduğu uzun zamandır bilinmektedir (Locke, 1976). Bilişsel iş tatmini, ücret, denetim ve çalışma koşulları gibi işin objektif şekilde değerlendirilmesini ifade eder. İşgörenler, kendi standartları veya diğer işlere kıyasla belirli iş yönlerinin ne kadar tatmin edici olduğunu değerlendirirler. Duyusal iş tatmini, işgörenlerin işlerinden ne kadar memnun veya mutlu olduklarını öznel olarak yansıtılmasını ifade eder (Visser, Lössbroek ve van der Lippe, 2020). Bunun yanı sıra iş tatmininin çeşitli bileşenleri, içsel ve dışsal iş özellikleri olarak gruplandırılmaktadır. Bireylerin işlerine yönelik tutumları açısından içsel parametreler, dışsal parametreler ise amirler, çalışanlar, ücret gibi çalışma ortamı parametreleri ile ilişkilidir (Anastasiou, 2020).

İş tatmini, üç özelliği ile toplumsal ve örgütsel anlamda dikkat çekmektedir (Eroğlu, 2020). Bunlar:

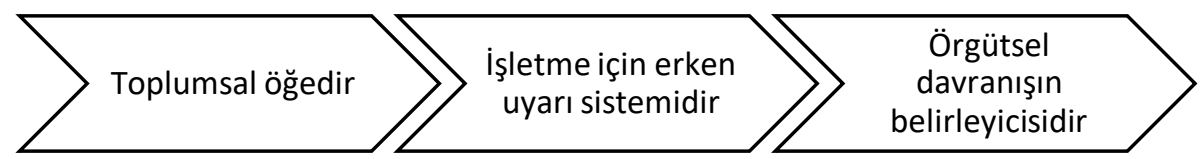

Şekil 3. İş tatmini unsurlar

Şekil incelendiğinde İş tatmini örgütsel boyutunun, işletmeler için önem arz ettiği anlaşılmaktadır. Zira Sökmen (2020), "devamsızlık, özdeşleşme, işten ayrılma niyeti, performans, örgütsel bağlılık, örgütsel vatandaşlık davranışı" gibi örgütsel konuların İş tatmininden etkilendiğini belirtmiştir.

Yukarıda verilen tanımların dışında İşgörenlerin, işleri ve işlerinin farklı yönleri hakkında düşünceleri de İş tatmininin konusunu oluşturmaktadır (Morton vd. , 2020). İş tatmini, işgörenlerin mevcut işlerine karşı kapsamlı bir tutum ve değerlendirmesidir, işle ilgili genel duygularına duygusal bir tepkidir ve işin verimliliği ve etkisi üzerinde öznel ve doğrudan etkiye sahiptir (Zhou, 2020). Özüne bakıldığında İş tatmini, "iş ile insan arasındaki uyumlu ilişkiyi” açıklamaktadır (Suvacı ve Nergiz). İş tatmini, yapılan çalışmalar neticesinde dokuz boyut altında değerlendirilmektedir (Aydoğan ve Şencan), (Aşan ve Erenler, 2008). Bunlar, 


\begin{tabular}{|c|c|}
\hline Ücret & $\begin{array}{l}\text { İşgören kendisi ile aynı işi yapan veya statüye sahip olan işgörenlerle aynı } \\
\text { ücreti almak ister. }\end{array}$ \\
\hline Terfi & $\begin{array}{l}\text { İşgörenler işlerinde uzun süreli çalıştıklarında, işlerinde yükselme ve daha } \\
\text { fazla sorumluluk hakkına sahip olmak isteyeceklerdir }\end{array}$ \\
\hline Yöneticiler & $\begin{array}{l}\text { İşgörenin cana yakın, anlayışlı ve eşit davranan bir yöneticiye sahip } \\
\text { olması, işteki performansının artmasına sebep olmaktadır }\end{array}$ \\
\hline Ek imkanlar & $\begin{array}{l}\text { Parasal ve parasal olmayan imkanların olması veya olmaması, çalışanların } \\
\text { işlerinden tatmin ya da tatminsizlik duymalarına neden olabilmektedir. }\end{array}$ \\
\hline Olası ödüller & $\begin{array}{l}\text { Tanınma ve iyi bir iş yapıldığında o iş için bir ödül alma olasıllı̆̆ının } \\
\text { bulunması, iş tatminini olumlu yönde etkileyebilmektedir. }\end{array}$ \\
\hline $\begin{array}{l}\text { İşleyiş } \\
\text { prosedürleri }\end{array}$ & $\begin{array}{l}\text { Örgüt içerisindeki işlerin işleyişi ve bu işlere ilişkin politika ve prosedürler, } \\
\text { iş tatmin düzeyini etkilemektedir. }\end{array}$ \\
\hline $\begin{array}{l}\text { İş } \\
\text { arkadaşları }\end{array}$ & $\begin{array}{l}\text { Grup içi elemanların teknik ve sosyal olarak yeterli ve destekleyici olup } \\
\text { olmamaları, iş tatmin düzeyini etkileyebilmekte ve tatmin düzeyini } \\
\text { değiştirebilmektedir. }\end{array}$ \\
\hline İşin kendisi & $\begin{array}{l}\text { Bazı işgörenlerin iş tatmini aldığı sorumluluktan dolayı artırırken, } \\
\text { bazılarının tatminsizlik duymasına neden olabilmektedir. }\end{array}$ \\
\hline İletişim & $\begin{array}{l}\text { Çalışanın örgütte ast-üst ilişkisinde bulunduğu ya da aynı düzeyde olduğu } \\
\text { diğer bireylerle iletişiminin arzu edilen düzeyde olması }\end{array}$ \\
\hline
\end{tabular}

\section{Şekil 4. Isş tatmini boyutlar}

Şekil 4'te verilen İş tatmini boyutlarına göre işgörenlerin motivasyonunun yüksek tutulduğu durumlarda tatmin duygusu yaşadığı anlaşılmaktadır.

\section{Yabancilaşma}

Yabancılaşma, kavramsal açıdan ilk kez Hegel tarafından "Tinin Görüngübilimi" (1807) adlı eserinde ele alınmıştır. Hegel'e göre yabancılaşma, "mutlak anlamda betimlenmemiş, kavranmamış insan yaşamının kolaylıkla doğaya yabancılaşacă̆ı" şeklinde açıklamışır (Yapıcı, 2004). Yabancılaşma, Latince "alienare" kökünden gelmektedir ve bir oluşu uzaklaştırma veya diğerinin yerine koyma, var olanın yerini değiştirme anlamlarında kullanılmaktadır (Şimşek, Balay ve Şimşek, 2012).

Yabancılaşma Çağlar (2012) tarafından "kurumsal ya da kişiler arası sorunların birey üzerinde yarattığı güçsüzlük, anlamsızlık, kuralsızlık, yalıtılmışlık ve kendine yabancılaşma duyguları" olarak tanımlanmıştır. Demirer 
ve Özbudun'dan (1998) aktaran E. Çelik ve Babaoğlan (2017), Yabancılaşmaya yönelik olarak geliştirilen tanımların "kavrayış ve algılama farklılaşmasının ortaya çıkması, dışarıdaki özellik ve yeteneklere ilgisizlik ve duyarsızlığın oluşması" çerçevesinde ortak özellik gösterdiğini ifade etmiştir. İşgören, yaptığ ması durumunda Yabancılaşma döngüsüne düşmektedir (Kaya ve Serçeoğlu, 2013).

Yabancilaşmanın 5 boyut altında incelenmesi gerektiği Eryılmaz ve Burgaz (2011) tarafından ifade edilmiştir. Bunlar:

\begin{tabular}{ll}
\hline Güçüzlük & $\begin{array}{l}\text { Üretilen ürünün bireyin kendisinden ayrı düşmesi, } \\
\text { yönetsel/örgütsel politikalar üzerinde etkide bulunma } \\
\text { açısından yetersizlik hissetmesi ve çalışma koşulları üzerinde } \\
\text { kontrol sahibi olamamasıdır. }\end{array}$ \\
\hline Anlamsızlık & $\begin{array}{l}\text { Örgütsel amaçların kişisel rollerle çatışmasıyla ortaya çıkan, } \\
\text { bütünleşmeyi engelleyen durumlardır. }\end{array}$ \\
\hline Kuralsızlık & $\begin{array}{l}\text { Belirlenen başarı hedeflerine ulaşabilmek için, bireyin } \\
\text { örgüt/toplum tarafından kabul görmeyen davranışları } \\
\text { benimsemesidir. }\end{array}$ \\
\cline { 2 - 3 } & $\begin{array}{l}\text { Örgüt bireylerinin kendi istekleriyle kendilerini çevrelerinden } \\
\text { geri çekmeleri ve uzaklaşmalarıdır. }\end{array}$ \\
\hline Yalıtılmışlık & \\
\hline Kendine & $\begin{array}{l}\text { İşgörenin yapmak ve başarmak istedikleriyle yaptığı işarasında } \\
\text { herhangi bir bağlantı kuramaması sonucunda, başarıdan } \\
\text { doğacak mutluluk duygusunu yaşayamamasıdır. }\end{array}$
\end{tabular}

\section{Şekil 5. Yabancılaşmanın boyutları}

Şekilde verilen boyutlar incelendiğinde Yabancılaşmanın temelinde bireyin kendisi, işyeri ve toplum ile yaşadığı kimlik sorunu yer aldığı görülmektedir.

Yabancılaşmanın işgören ve örgüt için sonuçlarını Turan ve Parsak (2011) aşağıda Şekil 6’da gösterildiği gibi aktarmışlardır. 


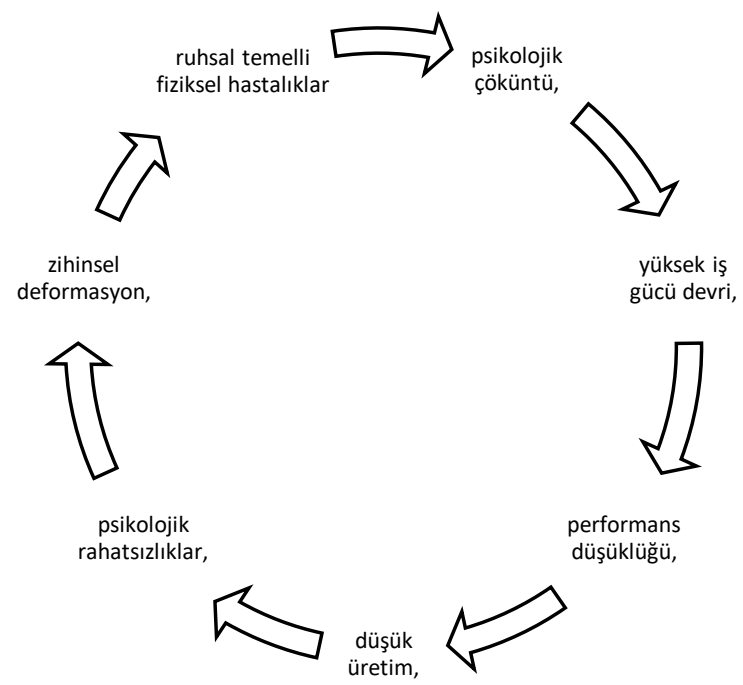

Şekil 6. Yabancılaşmanın sonuçlan

Sonuçlar incelendiğinde Yabancılaşmanın hem bireysel hem de örgütsel ve toplumsal sorunlara yol açacak sonuçlar doğurduğu anlaşılmaktadır. Bunun yanı sıra Mahmud (1994), sonuçların genel olarak pasif çekilme davranışına yol açtığını belirtmiştir. İşgörenler, yapılan işe ile ilgili olarak umdukları ortamı yakalayamadığında robotlaşmış hissine kapılabilir veya baskıcı ve sert yöneticiler ile çalıştığında yabancılaşarak saldırganlığa yönelebilir (Yalçın ve Koyuncu, 2014). Fromm'dan (1996) aktaran Şimşek ve Akdemir (2015), yabancılaşmaya yönelik olarak, yabancılaşmış işgörenin insanlardan uzaklaşırken kendisini de dışladığını ifade etmiştir.

\section{Değişkenler Arası İlişkilere Yönelik Yapılmış Çalışmalar}

Konu ile ilgili literatürde, Yabancılaşma ve İş tatmini arasındaki ilişkiyi incelemeye yönelik çalışma yapıldığı görülmektedir. Mantar yönetim ile İş tatmini ve Mantar yönetim ile Yabancılaşma arasındaki ilişkiyi inceleyen çalı̧̧malar bulunmamaktadır. Yabancılaşma ve İş tatmini ilişkisini inceleyen çalışmalarda aşağıdaki sonuçlara varılmıştır.

Tuğal, Topsakal ve İplik tarafından 2017 yılında yapılan çalışmada, örgütsel sağlık ve Yabancılaşma ilişkisinde örgütsel adalet aracı etkiye sahip iken İş tatmininin aracı etkisi bulunamamıştır. 
Yalçın ve Koyuncu tarafından 2014 yılında yapılan çalışmada Örgütsel yabancılaşmanın iş tatminini negatif yönde etkilediği bulunmuştur.

Mehmet ve Gülşah tarafından 2020 yılında yapılan çalışma 2010 yılında Parlak'ın yazdığı yüksek lisans tezini konu almaktadır. Bulgular açısından değerlendirildiğinde Yabancılaşma ve İş tatmini arasında negatif ilişki olduğu ispatlanmıştır.

Yabancı literatürde ise Shepard (1970), Orpen (1978), Lefkowitz ve Brigando (1980), Vecchio (1980) ve Hirschfeld (2002) Yabancılaşma ve İş tatmini ilişkisini incelemişlerdir. Bu yazarlardan Shepard tarafindan 1970 yılında yapılan çalışma, literatürde Yabancılaşma ve İş tatmini ilişkisini inceleyen ilk çalışma olması nedeni ile önem arz etmektedir. Çalışmaların tamamında İş tatmini ve Yabancılaşma arasında negatif ilişki bulunduğu vurgulanmıştır.

\section{Metodoloji}

Çalışmanın bu bölümünde, araştırmanın örneklem, evren, veri toplama yöntemi, araştırmada kullanılan ölçekler, araştırmanın modeli ve hipotezleri yer almaktadir.

\section{Çalışmanın Evreni, Örneklemi ve Veri Toplama Yöntemi}

Çalışmanın evreni, İstanbul ve Bursa illerinde ev tekstili sektöründe çalışan işgörenlerden; örneklem ise İstanbul ve Bursa illerinde seçilmiş ev tekstili sektöründe çalışan işgörenlerden oluşmaktadır. Ev tekstili, Ticaret Bakanlığı (2020) tarafından yayınlanan Ev Tekstili Sektör Raporuna göre "evleri dekore etmek amacıyla kullanılan ürünler" olarak tanımlanmakta ve ev tekstili hakkında "sentetik iplikler ve kumaşların yanı sıra, pamuk, keten, ipek ve yün gibi doğal ipliklerden yapılan kumaşlar da sektörün ham maddeleri arasında yer almaktadır" ifadesine yer verilmektedir. Sektörde üretilen ürünler döşemelik ve perdelik kumaş, yatak örtüleri ve diğer mefruşat eşyası, tüller ve dantelalar battaniyeler, masa örtüleri yastık, yorgan ve uyku tulumları, yatak çarşafları havlu ve bornozlar, perdeler ve yatak farbalaları, diğer ev tekstili ürünleri olarak listelenmektedir. Bursa özellikle havlu, tül ve çarşaf üretiminin; İstanbul ise tül ve çarşaf üretiminin yoğun olduğu illerdir. Dünya Ev tekstili sektöründe, 2019 yılında Türkiye tüm sektörün \%4,1'lik kısmını karşılayarak sektörün 4. ihracatçısı konumunda yer almaktadır. 
Araştırma, anket yöntemi kullanılarak gerçekleştirilmiştir. Değişkenler, 5’li Likert Ölçeğinde (1: Kesinlikle Katılıyorum, 5: Kesinlikle Katılmıyorum) ölçülmüştür. Örnekleme yöntemi olarak kolayda örnekleme metodu tercih edilmiştir. Bunun için İstanbul ve Bursa illerinde bulunan üretim tesislerine anket soruları 05.05.2020 tarihinde online olarak gönderilmiştir. Fakat coronovirüsü nedeni ile yaşanan pandemi sürecinde bazı işyerlerinin vardiyalı ve esnek çalışma şartlarını benimsemiş olmasından dolayı anket sorularının yanıtlanması 6 ay gibi uzunca bir süreye yayılmıştır. Anket için İstanbul'da 23, Bursa'da 14 işletmeye anket soruları online olarak ulaştırılmış ve anketlere İstanbul'dan 8 ve Bursa'dan 5 işletmenin işgörenleri katılmıştır. Uludağ İhracatçı Birlikleri (2020) web sayfasında yapılan firma arama işleminde Bursa'da 30; İstanbul Tekstil ve Hammaddeleri İhracatçıları Birliği (2020) web sayfasinda 279 adet ev tekstili ürünleri ihracatı yapan işletmeler bulunmaktadır. Bu durumda, anket yapılan ev tekstili işletmeleri, toplam ev tekstili işletmelerine göre Bursa'da \%16,6; İstanbul'da \%2,86 oranına tekabül etmektedir. Ankete Bursa'dan 58, İstanbul'dan 73 katılımcı iştirak etmiştir. Toplamda 131 katılımcı ile anket gerçekleştirilmiştir.

\section{Araştırmanın Ölçekleri}

Araştırmada kullanılan anket iki bölümden oluşmaktadır. Birinci bölümde demografik ve sosyo-ekonomik ifadelere yer verilmişken ikinci bölümde Mantar yönetim, İş tatmini ve Yabanclaşma değişkenleri yer almaktadır (Tablo 1).

Tablo 1. Çalışmanın Değişkenleri

\begin{tabular}{llllc}
\hline Değişken & $\begin{array}{l}\text { İfade } \\
\text { sayısı }\end{array}$ & Yazar & Yayın adı & $\begin{array}{c}\text { Yayım } \\
\text { yll }\end{array}$ \\
\hline $\begin{array}{l}\text { Demografik ve sosyo } \\
\text { ekonomik faktörler }\end{array}$ & 5 & & & 2017 \\
\hline Mantar yönetim & 8 & $\begin{array}{l}\text { Taşkın Kilıç } \\
\text { Hatun Olgun }\end{array}$ & Mantar Yönetim Yaklaşımı & 2020 \\
\hline İş tatmini & 6 & $\begin{array}{l}\text { Saadet Ela Pelenk } \\
\text { Ali Acaray }\end{array}$ & $\begin{array}{l}\text { Aşırı İş Yükünün İş Tatminine } \\
\text { Etkisinde İşyeri Maneviyatını } \\
\text { Düzenleyici Rolü }\end{array}$ & \\
\hline Yabancılaşma & 10 & İsmail Tokmak & $\begin{array}{l}\text { Duygusal Emek ile İşe } \\
\text { Yabanclaşma İlişkisinde Psikolojik } \\
\text { Sermayenin Düzenleyici Etkisi }\end{array}$ & 2014 \\
\hline
\end{tabular}


Tabloya göre, birinci bölümde katılımcılara yaş, eğitim, cinsiyet, çalışma yılı ve maaş bilgilerini içeren 5 adet demografik ve sosyo-ekonomik soru yöneltilmiştir. İkinci bölümde ise katılımcıların Mantar yönetim algısını ölçmek için 8; İş tatminini ölçmek için 6 ve Yabanclaşma durumunu ölçmek için 10 olmak üzere toplam 24 ifade yöneltilmiştir.

Mantar Yönetim Algısı Ölçeği: Mantar yönetim algısı ölçeği için Kılıç ve Olgun (2017) tarafından geliştirilen ölçek kullanılmıştır. Mantar yönetim Ölçeği geliştirmek için 3 akademisyen ve 2 yöneticiden 30 ifade toplanmıştır. Birbirine benzeye ifadeler birleştirildiğinde 12 ifade derlenmiştir. İlk olarak pilot çalışma gerçekleştirilmiş ve 3 ifade ölçekten çıkarılmıştır. Ardından yapılan analizlerde 1 ifade yeterli faktör yükü almadığı için veri setinden çıkarılmış ve Mantar yönetim algısı ölçeği 8 ifade ile ölçülebilir boyuta ulaşmıştır.

İş tatmini Ölçeği: Çalışmada kullanılan İş tatmini ölçeği, Pelenk ve Acaray (2020) tarafından geliştirilen 6 ifade ile ölçülmüştür. Pelenk ve Acaray, İş tatmini ölçeğini Tsui ve arkadaşlarının 1992 yılında yayınlamış oldukları çalışmadan uyarlamışlardır. Tsui ve arkadaşları çalışmalarını, Kaliforniya'da 1705 işgören ile anket çalışması yaparak gerçekleştirmişlerdir. Anket çalışması, 3 büyük işletmeye ait 151 üretim tesisinde psikolojik bağlllık, bulunmama, işte kalma niyeti ve İş tatmini değişkenleri arasındaki ilişkiyi ortaya çıkarmayı amaçlamıştır.

Yabancılaşma Ölçeği: Çalışmanın Yabancılaşma ölçeği, Tokmak (2014) tarafından kullanılan 10 ifade ile sınanmıştır. Ölçek, Hirschfeld, Feild ve Bedeianve'nin (2000) yılında yaptıkları çalışmadan Türkçe'ye Özbek (2011) tarafından kazandırılmıştır. 2014 yılında Kanten ve Ülker aynı ölçeği kullanarak geçerliliğini ve güvenilirliğini kanıtlamıştır. Hirschfeld ve arkadaşları iki farklı örnek grubu ile çalışma gerçekleştirmiş. İlk çalışma 2 hafta sürmüş ve 180 katılımcı yer almış; ikinci çalışma 3 hafta sürmüş ve 327 katılımcı iştirak etmiştir. Yapılan analizler neticesinde Yabancılaşma davranışını ölçmek için 10 ifade belirlenmiştir. 


\section{Çalışmanın Hipotezleri ve Modeli}

Hipotez, Lorcu (2015) tarafından “ortaya koyulan problemle ilişkili olarak yanitı aranacak sorular" veya "anakütle hakkında araştırma sonuna kadar geçici olarak düşündüğümüz test edilebilir varsayımlar" olarak tanımlamıştır. Çalışmaya ait hipotezler, literatür taraması neticesinde elde edilen bilgilere dayanarak geliştirilmiştir. Buna göre, araştırma hipotezleri:

- H1: Mantar yönetim algısının İş tatmini üzerine negatif ve anlamlı etkisi vardir.

- H2: Yabancilaşma, Mantar yönetim algısı ve İş tatmini ilişkisinde aracı etkiye sahiptir.

Çalısmanın hipotezleri verildikten sonra hipotezlere uygun modelin belirlenmesi gerekmektedir. Model kavramı, Özdemir (2008) tarafından, "teori ile yakın ilişkileri olan kavramların sistematik organizasyonunu ve kavramlar arasındaki ilişkileri ortaya koyan yapılardır. İlgilenilen problem üzerinde daha kavramsal ve yaratıcı düşünülmesine izin vermektedir" ş̧eklinde tanımlanmıştır. Çalışmaya ait model aşağıda Şekil 7'de verilmiştir.

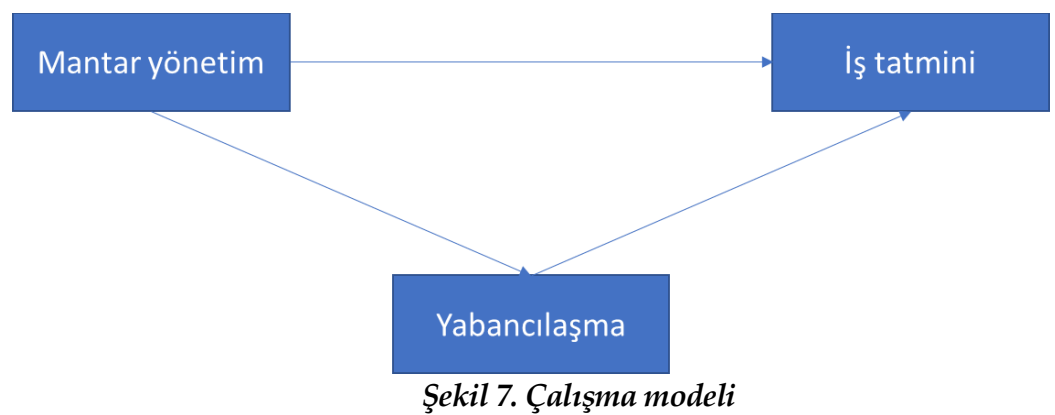

Şekilde verilen modele göre, Mantar yönetimin İş tatmini ilişkisinde, Yabancılaşma aracı etkiye sahiptir. Buradan hareketle, "Mantar yönetim alg1sına sahip işgörenlerde İş tatmini olgusu, Yabancılaşma hissinin varlığı ile değişim gösterir" demek mümkündür. 


\section{Geçerlilik ve Güvenilirlik Testleri}

Değişkenlere ilişkin geçerlilik analizleri, faktör analizi kullanılarak yapılmıştır. Faktör analizi, İslamoğlu ve Alnıaçık (2011) tarafından "değişkenler arasındaki ilişkilere dayanarak çok sayıdaki değişkeni daha az sayıdaki değişkene indirebilen çok değişkenli bir analiz tekniği" olarak ifade edilmiştir.

Tablo 2. Faktör ve güvenilirlik analizi

\begin{tabular}{lllll}
\hline Faktör & İfade & $\begin{array}{l}\text { Açılanan } \\
\text { Varyans (\%) }\end{array}$ & KMO Değeri & $\begin{array}{l}\text { Cronbach } \\
\text { Alfa }\end{array}$ \\
\hline Mantar yönetim & $\begin{array}{l}\text { MY1, MY2, MY3, MY4, MY5, MY6, } \\
\text { MY7, MY8 }\end{array}$ & $\% 61$ & .917 & .821 \\
\hline İş tatmini & İT1, IT2, IT3, İT4, İT5, İT6 & $\% 59$ & .941 & .835 \\
\hline Yabancılaşma & $\begin{array}{l}\text { YB1, YB2, YB3, YB4, YB5, YB6, YB7, } \\
\text { YB8, YB9, YB10 }\end{array}$ & $\% 62$ & .926 & .829 \\
\hline
\end{tabular}

Tabloya göre, KMO test sonuçları açısından tüm değişkenler faktör analizi için uygun bulunmuştur (Mantar yönetim KMO değeri 0.917, İş tatmini KMO değeri 0.941 ve Yabancılaşma KMO değeri 0.926). Faktör analizi sonuçlarına göre her üç değişken de tek boyut altında toplanmıştır. Mantar yönetim değişkeni kümülatif varyansı açılama oranı \%61, İş tatmini değişkeni kümülatif varyansı açıklama oranı $\% 59$ ve Yabancılaşma değişkeni kümülatif varyansı açıklama oranı \%62 olarak elde edilmiştir. Faktör yükü 0.500 'ün altında olan bir ifadeye rastlanmamıştır.

Çalışmanın güvenilirlik analizi için Cronbach Alfa katsayısından yararlanılmıştır. Lorcu (2015) Cronbach Alfa katsayısının alacağı değerler ile ilgili olarak “ $0 \leq \alpha<0.40$ : Ölçek Güvenilir Değil, $0.40 \leq \alpha<0.60$ : Ölçek Düşük Güvenilirlikte, $0.60 \leq \alpha<0.80$ : Ölçek Oldukça Güvenilir, $0.80 \leq \alpha<1.00$ : Ölçek Yüksek Derecede Güvenilir" olduğunu belirtmiştir. Bu çalışmada Cronbach Alfa değerlerinin 0.800 'ün üzerinde saptanmış olmasından dolayı ölçeklerin oldukça güvenilir olduğunu söylemek mümkündür.

Yukarıda verilen geçerlilik ve güvenilirlik analizleri sonucunda elde edilen veriler gözetilerek çalışmanın, korelasyon ve regresyon analizleri için uygun olduğu ifade edilebilir.

\section{Bulgular}

Çalışmanın bu bölümünde demografik verilere, korelasyon ve regresyon analizlerine ilişkin bulgulara yer verilmiştir. 


\section{Demografik Bulgular}

Araştırmaya katılım gösteren işgörenlere ait demografik ve sosyo-ekonomik veriler aşağıda tabloda verilmiştir.

Tablo 3. Demografik Veriler

\begin{tabular}{|c|c|c|c|c|c|c|c|}
\hline $\begin{array}{l}\text { Demogra- } \\
\text { fik Faktör }\end{array}$ & Alt Grup & $\mathbf{N}$ & $\begin{array}{l}\% \\
\text { Frekans }\end{array}$ & $\begin{array}{l}\text { Demografik } \\
\text { Faktör }\end{array}$ & Alt Grup & $\mathbf{N}$ & $\%$ Frekans \\
\hline \multirow[t]{3}{*}{ Yaş } & $20-35$ & 48 & 36,64 & \multirow[t]{4}{*}{ Eğitim } & İlköğretim & 10 & 7,63 \\
\hline & $36-50$ & 55 & 41,98 & & Lise & 23 & 17,56 \\
\hline & 51 ve üstü & 28 & 21,37 & & Üniversite & 85 & 64,89 \\
\hline \multirow[t]{2}{*}{ Cinsiyeti } & Kadın & 57 & 43,51 & & Lisans üstü & 13 & 9,92 \\
\hline & Erkek & 74 & 56,49 & \multirow[t]{3}{*}{ Çalışma Yilı } & $1-10 \mathrm{yll}$ & 18 & 13,74 \\
\hline \multirow[t]{3}{*}{ Maaş } & $0-3000 \mathrm{TL}$ & 11 & 8,40 & & $11-20$ yil & 76 & 58,02 \\
\hline & 3001-5000 TL & 67 & 51,15 & & 21 ve üstü & 37 & 28,24 \\
\hline & 5000 TL ve üstü & 53 & 40,46 & & & & \\
\hline
\end{tabular}

Tablo 3 incelendiğinde 36-50 ve 20-35 yaş gruplarının nispeten fazla olması $(\% 41,98-\% 36,54)$ genç sayılabilecek çalışma gruplarına işaret etmektedir. Ankete katılanların büyük çoğunluğu erkek işgörenlerden oluşmakta (\%56,49); 3001-5000 TL maaş aralığının fazla olduğu görülmekte (\%51,15); üniversite mezunu sayısının diğerlerine oranla yüksek olduğu anlaşılmakta $(\% 64,89)$ ve 11-20 yıl arası çalışma deneyimine sahip işgörenler ağırlıkta bulunmaktadır $(\% 58,02)$.

\section{Korelatif Bulgular}

Araştırma değişkenleri arasında ilişkileri incelemek üzere korelasyon analizi yapılmış ve değişken ortalamaları hesaplanmıştır. Bu amaçla, Mantar yönetim, İş tatmini ve Yabancılaşma değişkenlerinin ortalama, standart sapma ve korelasyon değerleri Tablo 2'de verilmiştir.

Tablo 4. Değişkenlerin ortalama, standart sapma ve korelasyonlan

\begin{tabular}{llllll}
\hline Değişkenler & Ortalama & Standart sapma & $\mathbf{1}$ & $\mathbf{2}$ & $\mathbf{3}$ \\
\hline Mantar yönetim & 3.01 & .97 & 1 & & \\
\hline İş tatmini & 3.11 & .86 & $-.339^{* *}$ & 1 & $.348^{* *}$ \\
\hline Yabancılaşma & 2.85 & .89 & $.368^{* *}$ & & 1 \\
\hline${ }^{* *} p<0.01$ & & & & & \\
\hline
\end{tabular}

Tablo 4 incelendiğinde araştırmanın bağımlı, bağımsız ve aracı değişkenleri arasında anlamlı ilişkiler olduğu görülmektedir. Buna göre, Mantar yönetim algısı ile İş tatmini ( $\mathrm{r}=-339$, $\mathrm{p}<0,01)$ değişkenleri arasında negatif yönlü ve anlamlı; Mantar yönetim algisı ile Yabancılaşma $(r=368, p<0,01)$ arasında 
pozitif yönlü ve anlamlı ve İş tatmini ile Yabancılaşma $(r=-348, p<0,01)$ değişkenleri arasında negatif yönde anlamlı ilişkiler bulunmaktadır. Buradan hareketle, Mantar yönetim algısına sahip işgörenlerin, İş tatmini yaşamasının beklenmediği ancak Yabancılaşma duygusuna kapılmalarının mümkün olduğu söylenebilir. Ayrıca, İş tatminine sahip işgörenlerin Yabancılaşma duygusu yaşaması beklenmemektedir.

\section{Regresyonal Bulgular}

Çalışmanın modeline uygun olarak, Mantar yönetim algısı ve İş tatmini ilişkisinde Yabancılaşmanın aracı etkisi sınanacaktır. Bu bağlamda üç aşamalı aracı değişken analizi yapmak gerekir. Baron ve Kenny'den (1986) aktaran Kanten ve Ülker (2014), üç aşamalı aracı değişken analizini “bağımsız değişkenin bağımlı değişken ve aracı değişken üzerinde bir etkisinin var olması gerekmektedir. Aracı değişken bağımsız değişkenle birlikte regresyon analizine dâhil edildiğinde, bağımsız değişkenin bağımlı değişken üzerindeki etkisinin azalması, aracı değişkenin de bağımlı değişken üzerindeki anlamlı etkisinin sürmesi beklenmektedir. Analizler sonucunda bağımsız değişkenin katsayısında düşüş olması kısmi aracılık, bu ilişkinin tamamen ortadan kalkması ise tam aracılık ilişkisi olarak ifade edilmektedir. Bununla birlikte bağımsız ve bağımlı değişken arasındaki ilişkilerin azalması ya da ortadan kalkmasının istatistiksel olarak açıklanabilmesi için Sobel testinin kullanılarak, hesaplanan z değerinin anlamlılı̆̆ına bakılması gerekmektedir" ifadelerine yer vermiştir.

Yukarıda verilen ifadeler doğrultusunda "Mantar yönetim algısı-İş tatmini" ve "Mantar yönetim algısı-Yabancılaşma" değişkenleri arasındaki ilişkiler hiyerarşik regresyon analizi yapılarak Sobel Testi uygulanmıştır. Aracılık analizi sonuçları aşağıda tabloda verilmiştir.

Tablo 5. Birinci adım Mantar yönetim-İş tatmini ilişkisi

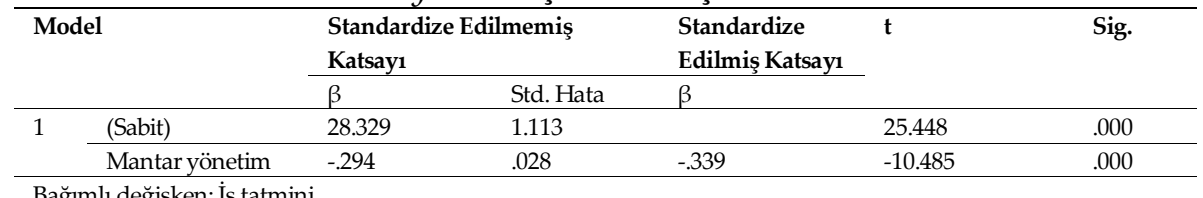


Tablo 5'te görüldüğü üzere Mantar yönetim-İş tatmini ilişkisi anlamlıdır $(\mathrm{p}<0.05)$ ve Mantar yönetim, İş tatminini negatif yönlü olarak etkilemektedir. Bu durumda, Mantar yönetim algısına sahip işgörenler İş tatminsizliği yaşamaktadır. Böylece çalışmanın 1. Hipotezi (Mantar yönetim algısının İş tatmini üzerine negatif ve anlamlı etkisi vardır) doğrulanmış olmaktadır.

Tablo 6. İkinci adım Mantar yönetim-Yabancılaşma ilişkisi

\begin{tabular}{|c|c|c|c|c|c|c|}
\hline \multicolumn{2}{|c|}{ Model } & \multicolumn{2}{|c|}{$\begin{array}{l}\text { Standardize Edilmemiş } \\
\text { Katsayı }\end{array}$} & \multirow{2}{*}{$\begin{array}{l}\text { Standardize Edilmiş } \\
\text { Katsayı } \\
\beta \beta\end{array}$} & \multirow[t]{2}{*}{$t$} & \multirow[t]{2}{*}{ Sig. } \\
\hline & & & & & & \\
\hline \multirow[t]{2}{*}{1} & (Sabit) & 10.229 & 3.197 & & 3.199 & .001 \\
\hline & Mantar yönetim & .927 & .081 & .368 & 11.498 & .000 \\
\hline
\end{tabular}

Tablo 6'ya göre Mantar yönetim-Yabancılaşma ilişkisi anlamlıdır $(\mathrm{p}<0.05)$ ve Mantar yönetim, Yabancılaşmayı pozitif yönlü olarak etkilemektedir. Buradan hareketle, Mantar yönetim algısına sahip işgörenlerin Yabancılaşma hissi yaşadı̆̆ 1 ifade edilebilir.

Tablo 7. Üçüncü adım Mantar yönetim, Yabancılaşma-İş tatmini ilişkisi

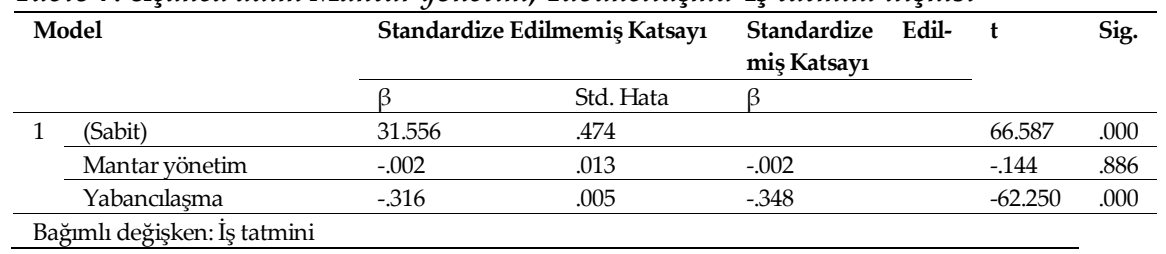

Tablo 7 incelendiğinde, Mantar yönetimin, İş tatmini üzerine etkisinde Yabancılaşma, aracı değişken olduğu zaman, Mantar yönetim beta değeri düşmekte (1. adım $\beta=-0.339,2$. adım $\beta=-0.002$ ), istatistiksel olarak anlamsızlaşmakta $(p=0.886>0.05)$ ve tam aracılık etkisi ortaya çıkmaktadır. Tam aracılık etkisi olmasından dolayı Sobel Testini yapmaya gerek kalmamıştır. Böylece çalışmanın 2. Hipotezi de (Yabancılaşma, Mantar yönetim algısı ve İş tatmini ilişkisinde aracı etkiye sahiptir) doğrulanmış olmaktadır. 


\section{Tartışma}

Literatürde, araştırmanın değişkenlerine ilişkin doğrudan bir çalışma bulunmadığı için elde edilen bulgular geçmiş yıllar ile karşılaştırılamamıştır. Geçmiş yıllarda yapılan çalışmalarda Yabancılaşma ve İş tatmini ilişkisi değerlendirilmiş fakat bu çalışmada Yabancılaşma ve İş tatmini ilişkisi araştırılmadığından kıyas imkânı bulunmamaktadır.

Çalışmada elde edilen bulgular değerlendirildiğinde birinci hipotezin ispatlanmış olduğu görülmektedir. Birinci hipotezde belirtilen "Mantar yönetim algısının İş tatmini üzerine negatif ve anlamlı etkisi vardır" ifadesinin doğruluğu, Mantar yönetimin olumsuz sonuçlarını gözler önüne sermektedir. Esasında, İş tatmini, bu hipotezde olduğu gibi sonuç olarak değil sebep olarak düşünüldügünde Mantar yönetimin olumsuz etkisi daha iyi anlaşılacaktır. Zira İş tatmini, yaşam tatmini ile (Aşan ve Erenler, 2008); işten ayrılma niyeti ile (G. G. Çelik, 2020); örgütsel bağlllık ile (Güler ve Bircan, 2020); işgören performansı ile (Öztürk ve Aygün, 2020); örgütsel özdeşleşme ile (Sökmen, 2020) istatistiksel olarak anlamlı etkileşime sahiptir. Bu durumda mantar yönetimin olumsuz sonuçlarını sadece İş tatmini ile sınırlandırmamak gerekmektedir.

Çalışmanın ikinci hipotezinde "Yabancılaşma, Mantar yönetim algısı ve İş tatmini ilişkisinde aracı etkiye sahiptir" ifadesi yer almaktadır. Hipotezin doğrulanması ile yönetimin uyguladığı mantar yönetimi tarzının İş tatminine etkisinde işgörenin yaşadığı Yabancllaşma hissinin önemli olduğu görülmektedir.

Mantar yönetim tarzını uygulayan işletmelerdeki işgörenlerin veya Mantar yönetim algısına sahip işgörenlerin Yabancılaşma hissine kapılabilecekleri, aracı değişken analizinin ikinci adımında ispatlanmıştı. Yabancılaşma hissi yaşayan işgörenlerde İş tatmini aksi yönde, olumsuz olarak etkilenmekte ve Mantar yönetim tarzı anlamını yitirmektedir. İşören, hem Mantar yönetim algısının olumsuz etkisi ile yüzleşmekte hem Yabancılaşma hissine kapılmakta hem de bunların doğal sonucu olarak iş tatminsizliği yaşamaktadır. Bu durumda, işgörenden performans beklemek haksızlık olacaktır. Yapılması gereken Mantar yönetim tarzından bir an evvel vaz geçmek olacaktır. Böylece işgören yabancılaşmasının önüne geçilebileceği gibi İş tatminsizliği ortadan kalkacak ve tatmin oluşacaktır. 


\section{Sonuç}

Bu çalışma, işgörenlerde Mantar yönetim algısının İş tatminine etkisinde Yabancılaşma hissinin aracı rolünü araştırmayı amaçlamıştır. Bu amaç doğrultusunda, çalışmada öncelikle kavramsal bilgilere yer verilmiştir. Mantar yönetim, İş tatmini ve Yabancılaşma kavramları açıklanmıştır. Çalışmanın metodolojisi olarak araştırma evrenini İstanbul ve Bursa illerinde ev tekstili sektöründe çalışan işgörenler; örneklemini ise İstanbul ve Bursa illerinde seçilmiş ev tekstili sektöründe çalışan işgörenler oluşmaktadır. Veri toplama yöntemi olarak anket kullanılmıştır. Online olarak gönderilen anketlere, Bursa'dan 58, İstanbul'dan 73 olmak üzere toplam 131 katılımcı iştirak etmiştir. Araştırmanın değişkenleri, Mantar yönetim (bağımsız değişken), İş tatmini (bağımlı değişken) ve Yabancılaşmadır (aracı değişken). Çalışma modeline göre, Mantar yönetim algısına sahip işgörenlerin İş tatmin düzeyine Yabancılaşma hissi aracılık etmektedir. Demografik verilerin analizi gerçekleştirilmiş, korelasyon analizi ile değişkenler arası ilişkiler ortaya konmuş ve regresyon analizi ile araştırma hipotezleri sınanmıştır. Öne sürülen her iki hipotez de ispatlanmıştır. Buna göre Mantar yönetim algısının İş tatmini üzerine negatif ve anlamlı etkisi bulunduğu gibi Yabancılaşma, Mantar yönetim ve İş tatmini ilişkisinde aracıya etkiye sahiptir.

Çalışma bulguları, işletmeler üzerinde rahatlıkla realize edilebilecek sonuçlar vermektedir. Mantar yönetim tarzı uygulayan işletmeler, sonuçları deneme yanılma yöntemi ile bulmak yerine bu tarzın, olumsuz birçok duruma yol açabileceği fikrinden hareketle yönetim tarzını değiştirmek isteyecektir. Çünkü Mantar yönetim, Yabancılaşmaya ve akabinde iş tatminsizliğine yol açabilir.

Çalışma çeşitli kısıtlara sahiptir. Bunların başında coronavirüs salgını nedeni ile pandemi sürecinin olumsuz etkileri gelmektedir. Ayrıca ev tekstili sektörü ile sınırlandırılmış olması çalışmayı kısıtlamaktadır. İlerili yıllarda yapılacak çalışmalarda Mantar yönetimi etkileyen unsurlara değinilebilir, evren ve örneklem çeşitlendirilebilir ve nitel araştırma yöntemleri denenebilir. 


\section{EXTENDED ABSTRACT}

\section{The Mediating Role of Alienation in the Effect of Mushroom Management Perception on Job Satisfaction \\ Olgun Irmak Çetin \\ Trakya University}

The basis of mushroom management is using the method of growing mushrooms in the dark as a metaphor. It is evaluated as the manager being deprived of one-sidedness in communication by preventing employees from accessing information and leaving them in the dark. Job satisfaction is defined as the positive opinion of the employee as a result of reviewing his/her job or his/her experiences related to the job. In other words, it refers to all beliefs that include the work of the employees that are currently in progress. Job satisfaction has important contents for both human resources and behavioral sciences since it has been a subject of research for many years in the business literature. It has long been known that job satisfaction has cognitive and sensory components. Cognitive job satisfaction refers to the objective evaluation of the job such as wages, supervision and working conditions. Employees judge how satisfying certain business aspects are compared to their own standards or other jobs. Sensory job satisfaction refers to the subjective reflection of how satisfied or happy employees are with their job. Conceptually, alienation was first addressed by Hegel in his "Phenomenology of Spirit" (1807). Hegel stated that human life, which is not described and understood in an absolute sense, will easily alienate from nature. Alienation comes from the Latin root "alienare" and is used in the sense of removing one being or substituting for another, replacing the existing.

It is seen that most of the studies on alienation in the literature are aimed at examining the relationship between Alienation and Job satisfaction. In all of the studies, it has been determined that there is a negative relationship between Job satisfaction and Alienation.

The universe of the study is among the employees working in the home textile sector in Istanbul and Bursa provinces; The sample consists of selected 
employees working in the home textile industry in Istanbul and Bursa provinces. The research was carried out using the survey method. Variables were measured on a 5-point Likert Scale (1: Strongly Agree, 5: Strongly Disagree). A survey was conducted with a total of 131 participants. 58 participants from Bursa and 73 participants from Istanbul participated in the survey. The questionnaire used in the study consists of two parts. While demographic and socio-economic expressions are given in the first part, the variables of Mushroom management, Job satisfaction and Alienation are included in the second part. The scale developed by Kılıç and Olgun (2017) was used for the mushroom management perception scale. The job satisfaction scale used in the study was measured with 6 statements developed by Pelenk and Acaray (2020). The Alienation scale of the study was tested with 10 expressions used by Tokmak (2014).

The hypotheses for the study were developed based on the information obtained as a result of the literature review. Accordingly, the research hypotheses are:

- $\quad$ H1: Mushroom management perception has a negative and significant effect on job satisfaction.

- $\quad H 2$ : Alienation has a mediating effect on the perception of mushroom management and job satisfaction.

According to the research model, Alienation has a mediating effect in the relationship between mushroom management and job satisfaction. From this point of view, it is possible to say that "in employees with a mushroom management perception, the phenomenon of job satisfaction changes with the presence of a feeling of Alienation".

Validity analyzes for variables were made using factor analysis. Explanation rate of the cumulative variance of the mushroom management variable was $61 \%$, the explanation rate of the cumulative variance of the job satisfaction variable was $59 \%$, and the explanation rate of the cumulative variance of the Alienation variable was 62\%. An expression with a factor load below 0.500 has not been found.

Cronbach Alpha coefficient was used for the reliability analysis of the study. In this study, it is possible to say that the scales are quite reliable since the Cronbach Alpha values were determined to be above 0.800 .

It is seen that there are correlatively significant relationships between the dependent, independent and mediator variables of the study. Accordingly, 
there are negative and significant relationships between the perception of mushroom management and job satisfaction $(\mathrm{r}=-339, \mathrm{p}<0,01)$ variables; There are positive and significant relationships between the perception of mushroom management and Alienation $(r=368, p<0,01)$ variables, and negative and significant relationships between Job satisfaction and Alienation $(\mathrm{r}=-348, \mathrm{p}<0,01)$ variables.

The relationships between "Mushroom management perception-Job satisfaction" and "Mushroom management perception-Alienation" variables were performed by hierarchical regression analysis and Sobel Test was applied.

As a result of the analysis, Mushroom management-Job satisfaction relationship was found to be significant $(\mathrm{p}<0.05)$ and Mushroom management negatively affects job satisfaction. In this case, employees with a mushroom management perception experience job dissatisfaction. Thus, the first hypothesis of the study (Mushroom management perception has a negative and significant effect on job satisfaction) is confirmed. As a result of hierarchical regression analysis, when Alienation is the mediator variable in the effect of mushroom management on job satisfaction, the mushroom management beta value decreases (1st step $\beta=-0.339$, 2nd step $\beta=-0.002$ ), it becomes statistically insignificant $(p=0.886>0.05)$ and the full mediation effect emerges. There is no need to do the Sobel Test due to its full mediation effect. Thus, the second hypothesis of the study (Alienation has a mediating effect in the relationship between Mushroom management perception and Job satisfaction) is confirmed as well.

In the second step of the intermediary variable analysis, it was proved that the employees in the enterprises applying the mushroom management style or the employees with the mushroom management perception can feel Alienation. Job satisfaction is adversely affected in employees who experience a feeling of alienation and the Mushroom management style loses its meaning. Employee is confronted with the negative effect of the perception of mushroom management, feels alienation and also experiences job dissatisfaction as a natural result of these. In this case, it would be unfair to expect performance from the employee. What needs to be done is to give up the mushroom management style as soon as possible. Thus, employee alienation can be prevented, job dissatisfaction will also disappear and satisfaction will be created. 


\section{Kaynakça / References}

Alnıaçık, E., Pamuk, M., ve Alnıaçk, Ü. (2020). Kurumsal imajin bağllık, iş tatmini ve işten ayrılma niyeti üzerindeki etkileri: Sağlık çalışanları üzerindebir araştırma Balkan ve Yakm Doğu Sosyal Bilimler Dergisi, 06(04), 43-55.

Amoah, R. (2020). Assessing job satisfacion among the workers of Ghana Water Company Limited (GWCL) in Ashanti South Region. (Yayımlanmamış doktora tezi). Christian Service University College, Ghana.

Anastasiou, S. (2020). The significant effect of leadership and conflict management on job satisfaction. Academic Journal of Interdisciplinary Studies, 09 (06), 9-17

Aşan, Ö., ve Erenler, E. (2008). İş Tatmini ve Yaşam Tatmini Ilişkisi Süleyman Demirel Üniversitesi Ï̈BF Dergisi, 13(2), 203-216.

Atagan Çetin, A. (2017). Kurumsal sosyal sorumluluk ve etik ilişkisi. 2nd International Trakya Accounting Finance and Auditing Symposium

Aydoğan, M., ve Şencan, H. (2019). İstihdam markası ve işletme performansı faktörlerinin iş tatmini üzerindeki etkisi. İstanbul Ticaret Üniversitesi Girişimcilik Dergisi, 3(6), 89-99.

Birincioğlu, N., ve Tekin, E. (2018). Mantar yönetim ölçeği geliştirilmesi üzerine bir çalışma. Business and Economics Research Journal, 9(1), 169-186.

Çağlar, Ç. (2012). Öğrenci yabanclaşma ölçeği'nin (ÖYÖ) geliştirilmesi. Eğitim ve Bilim Dergisi, 37(166).

Çelik, E., ve Babaoğlan, E. (2017). Üniversite öğrencilerinin yabanclaşma düzeyi. Ahi Evran Üniversitesi Kirşehir Eğitim Fakültesi Dergisi, 18(1), 405-427.

Çelik, G. G. (2020). Öğretmenlerin İsten ayrılma niyetlerinde iş tatmini, örgütsel bağlllık ve tükenmişliğin rolü. Avrasya Sosyal ve Ekonomi Araştırmalarn Dergisi, 7(7), 276294.

Çelik, Y., ve Demir, B. (2020). İs görenlerin iş tatmini ve örgütsel bağlllık düzeylerinin performansları üzerindeki etkisinin incelenmesi. İstanbul Kent Üniversitesi İnsan ve Toplum Bilimleri Dergisi, 1(2), 29-49.

Çınar, F., ve Toker, K. (2019). Hastane yöneticilerinin stratejik yönetim araçlarını bilme ve kullanım düzeylerinin örgütsel inovasyona etkisi. Social Sciences, 14(5), 2117-2134.

Ergün, H. (2020). Mantar tipi yönetim ölçeği. Paper presented at the EJER Congress 2020, Eskişehir.

Eroğlu, A. (2020). İş yükünün işten ayrilma niyeti üzerine etkisinde iş tatmini ve kişiörgüt uyumunun aracllk rolü. İs ve İnsan Dergisi, 7(2), 213-227.

Erylmaz, A., ve Burgaz, B. (2011). Özel ve resmi lise öğretmenlerinin örgütsel yabanc1laşma düzeyleri. Ĕ̈̆itim ve Bilim, 36(161). 
Essien, E. (2020). An assessment of job satisfaction levels of teachers in junior high schools in the amansie west district assembly. Yayımlanmamış doktora tezi. Christian Service University College, Ghana.

Gunn, B. (1995). The paradigm shift in university management. International Journal of Educational Management. 09(01), 28-40

Güler, A., ve Bircan, H. (2020). İdari personelin iş tatmini ve örgüte bağlılığına etki eden faktörlerin belirlenmesi: Sivas Cumhuriyet Üniversitesi örneği. Ahi Evran Üniversitesi İktisadi ve İdari Bilimler Fakültesi Dergisi, 4(1), 10-33.

Hirschfeld, R. R. (2002). Achievement orientation and psychological involvement in job tasks: The interactive effects of work alienation and intrinsic job satisfaction. Journal of Applied Social Psychology, 32(8), 1663-1681. doi:10.1111/j.15591816.2002.tb02768.x

İslamoğlu, A. H., ve Alnıaçık, Ü. (2011). Sosyal bilimlerde araştırma yöntemleri (2 ed.). İstanbul: Beta Yayınevi.

İstanbul Tekstil ve Hammaddeleri İhracatçları Birliği. (2020). Üye Listesi. http://www.ithib.org.tr/tr/exporters.html?Gtip=\&SearchText=ev+tekstili\&ProductGrup $=\&$ CountryId $=\&$ CityId $=34 \&$ Page $=3 \& S o r t=\% 7 \mathrm{~B} \% 22$ id.FRMUNVAN\%22\%3A1\%7D adresinden erişilmiştir.

Kahya, V., ve Ceylan, E. (2019). İş performansını artırmada yeni bir yaklaşım: Mantar yönetim. Uluslararası Sosyal ve Beşeri Bilimler Araştırma Dergisi, 4(45), 3773-3781.

Kanten, P., ve Ülker, F. (2014). Yönetim tarzının üretkenlik karşıtı iş davranışlarına etkisinde işe yabancılaşmanın aracılık rolü. Mugla Sitki Kocman University Journal of Social Sciences, 32.

Kaya, U., ve Serçeoğlu, N. (2013). Duygu işçilerinde işe yabancılaşma: Hizmet sektöründe bir araştırma. Calisma ve Toplum, 36(1).

Kılıç, T., \& Olgun, H. (2017). Mantar yönetim yaklaşımı. Örgütsel Davranış Araştırmalan Dergisi, 2(2), 105-113.

Külekçi, M. K., Özbozkurt, O. B., ve Bahar, E. (2020). The mediating role of mushroom management within the impact of job stress on intention to leave. İşletme Araştırmalarn Dergisi, 12(1).

Lefkowitz, J., ve Brigando, L. (1980). Redundancy of work alienation and job satisfaction: some evidence of convergent and discriminant validity. Journal of Vocational Behavior, 16, 115-131.

Lorcu, F. (2015). Örneklerle veri analizi SPSS uygulamalı (1 ed.). Ankara: Detay Yayıncilı. Mahmud, Z. K. (1994). Work alienation and training: A study of Florida Correctional Officers and Correctional Officer Sergeants. (Yayımlanmamış doktora tezi). Florida State University, Amerika Birleşik Devletleri. 
Mar, A. (2011). Mushroom management. https://management.simplicable.com/management/new/mushroom-management adresinden erişilmiştir.

Mehmet, T., ve Gülşah, P. (2020). Yabanclaşma ve iş tatmini ilişkisi: Bir devlet üniversitesi idari personeli üzerinde araştırma. The relationship between job satisfaction and alienation: A research on a state university administrative personnel, 20(2), 1-20.

Morton, D., Bower, C., Wessels, L., Koen, A., ve Tobias, J. (2020). Job satisfaction of registered nurses in a private critical care unit in the eastern cape: A pilot study. Health SA Gesondheid, 25, 9.

Orpen, C. (1978). Discrimination, alienation, and job satisfaction among Coloured and White employees in South Africa. International Journal of Psychology, 13(1), 59. doi:10.1080/00207597808246614

Özdemir, A. (2008). Yönetim biliminde ileri araştırma yöntemleri ve uygulamalar (3 ed.). İstanbul: Beta Yayınları.

Öztürk, A. T., ve Aygün, İ d. K. (2020). İş tatmini ve işgören performansı arasındaki ilişki üzerinde iş stresinin aracllik rolünün belirlenmesi. Gazi İktisat ve Işletme Dergisi, 6(3), 210-234.

Paithankar, P. S. (2020). A study of job satisfaction in municipal doctors. International Journal of Scientific Development and Research, 05(11), 152-156

Pelenk, S. E., ve Acaray, A. (2020). Aşırı iş yükünün iş tatmninne etkisinde işyeri maneviyatının düzenleyici rolü Süleyman Demirel Üniversitesi Vizyoner Dergisi, 11(27), 480-497.

Shepard, J. M. (1970). Functional spezilation, alienation, and job satisfaction. ILR Review, 23(2), 207-219. doi:10.1177/001979397002300203

Sökmen, A. (2020). Lider üye etkileşimi, iş tatmini ve örgütsel özdeşleşme ilişkisi: Ankara' daki otel. Journal of Tourism and Gastronomy Studies, 8(3), 2132-2143.

Suvacı, B., \& Nergiz, G. (2020). Banka çalışanlarının iş stresi ve iş tatmini düzeylerinin belirlenmesi: bursa ili örneği. Uluslararası Yönetim ve Sosyal Bilimler Kongresi.

Şimşek, H., ve Akdemir, Ö. A. (2015). Üniversite öğrencilerinde okula yabancılaşma. Current Research in Education, 1(1), 1-12.

Şimşek, H., Balay, R., ve Şimşek, A. S. (2012). İköğretim sınıf öğretmenlerinde mesleki yabancılaşma. Eğitim Bilimleri Araştırmalan Dergisi, 2(1), 53-72.

Tekin, E., ve Birincioğlu, N. (2017). Bilgi çağının odak noktası üniversitelerde mantar yönetimi. International Journal of Academic Value Studies, 03(14), 22-29.

Ticaret Bakanlığı. (2020). Ev tekstili sektör raporu. https://ticaret.gov.tr/data/5b87000813b8761450e18d7b/Ev\%20Tekstili\%20Raporu.pdf adresinden erişilmiştir. 
Tokmak, İ. (2014). Duygusal emek ile işe yabancılaşma ilişkisinde psikolojik sermayenin düzenleyici etkisi. İsletme Araştırmaları Dergisi, 6(3), 134-156.

Tuğal, F. N., Topsakal, Y., ve İplik, E. (2017). Örgütsel sağlı̆̆ın çalışanların iş tatmini ve yabanclaşma düzeyine etkisinde örgütsel adaletin aracı rolü. The Mediating Role of Organizational Justice in the Effect of Organizational Health on Job Satisfaction andAlienation Levels of Employees., 7(3), 479-488.

Turan, M., ve Parsak, G. (2011). Yabanclaşma ve iş tatmini ilişkisi: bir devlet üniversitesi idari personeli üzerinde araştırma. Çukurova Üniversitesi Sosyal Bilimler Enstitüsü Dergisi, 20(2), 1-20.

Uludağ İhracatçı Birlikleri. (2020). Üye Listesi. http://uib.org.tr/tr/members.html? $q=e v+$ tekstil \&b=402\&c=BURSA\& $p=0$ adresinden erişilmiştir.

Vecchio, R. P. (1980). Worker Alienation as a Moderator of the Job Quality-Job Satisfaction Relationship: The Case of Racial Differences. Academy of Management Journal, 23(3), 479-486. doi:10.2307/255513

Visser, M., Lössbroek, J., ve van der Lippe, T. (2020). The Use of HR Policies and Job Satisfaction of Older Workers. Work, Aging and Retirement.

Yalçın, İ., ve Koyuncu, S. C. (2014). Örgütsel yabancllaşma olgusunun iş tatmini üzerine etkisi: Niğde İinde bir araştırma. Karamanoğlu Mehmetbey Üniversitesi Sosyal ve Ekonomik Araştırmalar Dergisi, 1, 86-94.

Yapıcı, M. (2004). Eğitim ve yabancılaşma. Journal of Human Sciences, 1(1).

Yücekaya, P., ve Dönmez Polat, D. (2020). Örgüt kültürü, örgütsel adalet ve iş tatmini ilişkisi üzerine bir araştırma. Iş̧letme Araştırmalarn Dergisi, 12(2), 1267-1284.

Zhou, D. (2020). Analysis on the influencing factors and countermeasures of job satisfaction reduction based on employees' personal perspective. Modern Economics E Management Forum, 1(3), 103-108.

\section{Kaynakça Bilgisi / Citation Information}

Çetin, I, O. (2021). Mantar yönetim algısının iş tatminine etkisinde yabancılaşmanın aracı rolü. OPUS-Uluslararası Toplum Araştırmaları Dergisi, 17(33), 398-424. DOI: 10.26466/opus.845473 